\title{
RESEÑA. NARRATIVAS DE MULHERES EDUCADORAS MILITANTES NO CONTEXTO AUTORITÁRIO BRASILEIRO (1964-1979)
}

\section{REVIEW. NARRATIVAS DE MULHERES EDUCADORAS MILITANTES NO CONTEXTO AUTORITÁRIO BRASILEIRO (1964-1979)}

Lia Machado Fiuza Fialho Universidade Estadual do Cerará, Brasil https://orcid.org/0000-0003-0393-9892 lia_fialho@yahoo.com.br

Arliene Stephanie Menezes Pereira Universidade Estadual do Cerará, Brasil https://orcid.org/0000-0002-3042-538X stephanie_ce@hotmail.com

Autores: José Gerardo Vasconcelos y Marta María de Araújo

Editorial: EdUECE: Brasil

Año: 2016

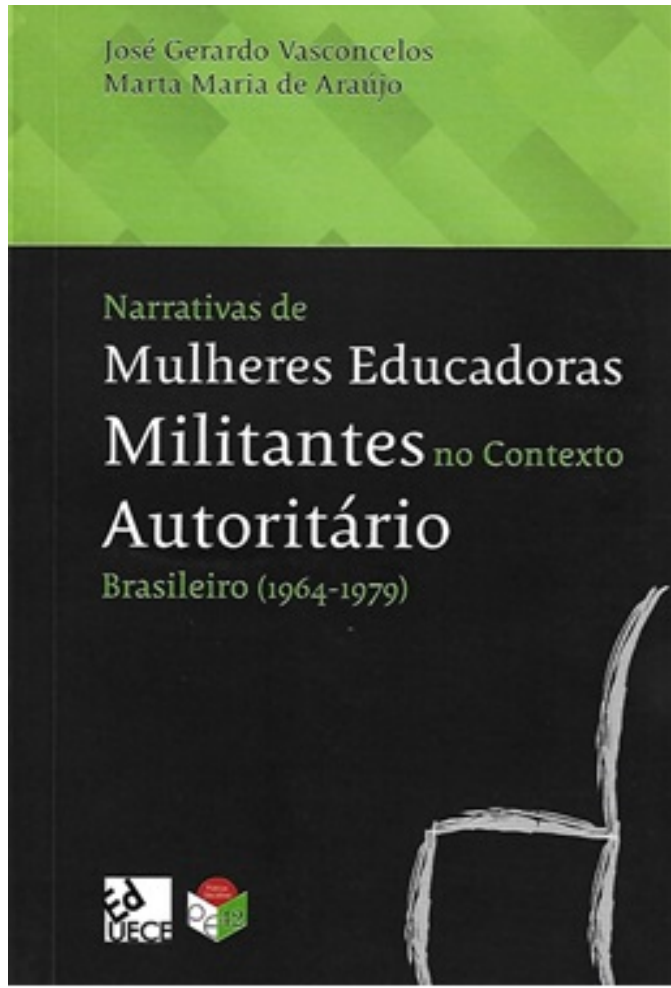

Narrativas de

Mulheres Educadoras Militantes no Contexto Autoritário Brasileiro (1964-1979)

Cómo citar este artículo: Fialho, L, M. F. y Pereira, A.S.M. (2020). Reseña. "Narrativa de mulheres educadoras militantes no contexto autoritário brasileiro (1964-1979)". Hachetetepé. Revista cientifica en Educación y Comunicación, (20), 110-111.doi: http://doi.org/10.25267/Hachetetepe.2020.i20.14

El libro trae el contexto de mujeres que luchan "contra un poder hegemónico, revelando secretos ocultos" (p. 9). Permite reflexiones críticas sobre el golpe de estado de 1964 en Brasil, conocido como la dictadura militar (1964-1979), en los que los e-ISSN:2172-7910

Doi: http://doi.org/10.25267/Hachetetepe.2020.i20.14 
militares instalaron un régimen autoritario-burocrático en el país que sustrajo derechos constitucionales, como, el desarrollo de elecciones directas, con estricto control de la participación política de la población.

Se fomentan las reflexiones críticas al contextualizar históricamente el momento dictatorial brasileño al alertar para comprender lo que sucedió en Brasil en 2016, la destitución de la presidenta elegida democráticamente, Dilma Rousseff, que culminó en la reanudación del poder por parte de representantes de la derecha conservadora. A partir de esto, traen la trayectoria de los movimientos de izquierda en el país en 1964, que con el golpe vivieron sus primeros momentos de pánico con las prisiones multiplicadas, los actos de tortura, la salida al exilio y lo clandestino, legitimando una cultura del miedo.

El régimen dictatorial trajo construcciones simbólicas que exaltaban el heroísmo a los militares, especialmente porque estaba destruyendo enemigos por una causa revolucionaria y patriótica, en la dirección opuesta, dando lugar a una sensación de vergüenza para los denunciantes y opositores. Sin embargo, el régimen no pudo dominar y silenciar a toda la sociedad civil, a pesar de que los opositores fueron fuertemente reprimidos. Tal enfrentamiento resultó en el exilio, en la tortura y en la muerte de algunas personas, relegando a las mujeres a los sótanos de la memoria.

El libro valora la narrativa de las mujeres que han experimentado esta situación histórica y argumenta que fueron las pioneras en la lucha por la amnistía; involucrarse en la defensa de sus hijos, parientes y amigos, y hacer un movimiento de resistencia con un carácter humanista que se atrevió a desafiar al régimen autocrático. La lectura sobre el tema de la militancia femenina ha sido aclarada desde los testimonios de dos mujeres: la profesora Rosa da Fonseca, presa en 1964; y la Sra. Regina Celia Zanetti, una activista clandestina. Ambos cuestionaron el sistema político dictatorial y se opusieron a las restricciones a la libertad de pensamiento y la democracia, siendo perseguidos.

Rosa da Fonseca, fundadora del Partido Revolucionario de los Trabajadores para la Revolución Humana, fue arrestada y torturada. Actualmente es parte del movimiento de Crítica Radical, que propone el fin de la política como una forma de emancipación y propone un proceso revolucionario fortalecido. Celia Zanetti, también miembro de Crítica Radical, tomó el camino de la oscuridad de la clandestinidad que "era un proyecto político que tenía como objetivo luchar contra el poder establecido, existir individualmente" (p. 80). La fluidez discursiva permitió encontrar la memoria familiar de los excluidos con la "frontera entre el dicho y lo inefable, lo confesable y el silencio". (p. 81), sin descuidar la confusión de los recuerdos y olvidos.

Destaca el año 1975, en el que un grupo de mujeres, entre ellas Rosa Fonseca y Celia Zanetti, lanzaron un manifiesto a la nación en la lucha por la amnistía, incluso sin grandes movimientos populares, ya que el régimen no lo permitió, ocupando un espacio político que hasta entonces estaba dirigido principalmente a hombres. El movimiento comenzó primero con un carácter de lucha por familiares desaparecidos o torturados, en el que "las mujeres vuelven al hilo conductor de la sociedad civil en el sentido de unir y fortalecer las instituciones democráticas" (p. 57). Para eso, se necesitaban voces femeninas para encarnar este logro, y es en este contexto que el trabajo proporciona una reflexión sobre los dilemas y secciones de los políticos perseguidos a través de la narrativa de las mujeres.

Vasconcelos, J.G. y De Araújo, M. Ma. (2016). Narrativas de mulheres educadoras militantes no contexto autoritário brasileiro (1964-1979). Brasil: EdUECE

e-ISSN:2172-7910

Doi: http://doi.org/10.25267/Hachetetepe.2020.i20.14

Universidad de Cádiz 